\title{
PENGARUH PERILAKU PEMIMPIN, KARAKTERISTIK TUGAS DAN HARAPAN BAWAHAN TERHADAP KEPUASAN ATAS KEPEMIMPINAN DI LINGKUNGAN DINAS PENDIDIKAN KABUPATEN DONGGALA SULAWESI TENGAH
}

\begin{abstract}
ASPINA*
Abstract: Subordinates' satisfaction to the leadership in an organization is assumed to be affected by the leaders' behavior, the task characteristics and their expectancies. The study reported here aimed to examine how the three variables actually affected the subordinates' satisfaction to the leadership in the office of education of the Donggala Regency, Central Sulawesi, and also how they affected each other. The causal study was conducted in the form of a survey to the employees in the Donggala Regency in their capacities as subordinates. The sample consisted of 97 employees, randomly selected from the overall number of employees of 129. The data of each variable were collected separately with a questionnaire. A path technique was employed to analyze the data with the SPSS technique. Result show direct effects of the leaders' behaviors and the characteristics of the tasks on the subordinates' expectancies, direct effects of subordinates' expectancies on their satisfaction to the leadership style, but indirect effects of the leaders' behaviors and the task characteristics on the subordinates' satisfaction to the leadership through their expectancies. These findings suggest that the variables of leaders' behaviors' task characteristics, and subordinates' expectancies are important determinants of satisfaction to the leaderhips. Improvement in the satisfaction to the leadership style my be therefore be expected by improved behaviors of the leaders, characteristics of the tasks and the subordinates' expectancies.
\end{abstract}

Keywords: Leaders' Behavior, Task Characteristics, Expectancies, Satisfaction.

\section{PENDAHULUAN}

Salah satu komponen organisasi yang sangat menentukan dalam mencapai tujuan yang diinginkan adalah peranan manusia sebagai pelaku organisasi. Meskipun peran manusia dalam organisasi diakui, tetapi tidak berarti berhenti mempermasalahkannya, sebab manusia merupakan elemen organisasi yang dinamik dan senantiasa berubah menurut kondisi sekitarnya. Permasalahan yang berkembang dalam aspek hubungan manusia dalam organisasi saat ini di Lingkungan Dinas Pendidikan Kabupaten Donggala Sulawesi Tengah adalah permasalahan kepemimpinan, khususnya adanya ketidakpuasan atas kepemimpinan. Hal ini berkaitan dengan faktor-faktor mengapa pegawai di Lingkungan Dinas Pendidikan ini kurang bersemangat dan bergairah mengerahkan daya upaya untuk melakukan suatu pekerjaan.

Dinas Pendidikan Kabupaten Donggala ini sendiri mengelola empat bidang yaitu Bidang Pendidikan Dasar dan Usia Dini, Bidang Pendidikan Menengah, Bidang Pendidikan Informal dan Non Formal, dan Bidang Peningkatan Mutu Pendidik dan Tenaga Kependidikan. Bidang Pendidikan Dasar dan Usia Dini terdiri dari (1) Seksi Administrasi dan Manajemen TK dan Pendidikan Dasar; (2) Seksi Kurikulum dan Sistem Pengkajian TK dan Pendidikan Dasar; (3) Seksi Sarana dan Prasarana TK dan Pendidikan Dasar. Bidang Pendidikan Menengah terdiri dari (1) Seksi Administrasi dan Manajemen Pendidikan Menengah; (2) Seksi Kurikulum dan Sistem Pengkajian

\footnotetext{
* Guru SMPN Banawa Kabupaten Donggala Propinsi Sulawesi Tengah
} 
Pendidikan Menengah; (3) Seksi Sarana dan Prasarana Pendidikan Menengah. Bidang Pendidikan Informal dan Non Formal terdiri dari (1) Seksi Administrasi dan Manajemen Pendidikan Informal dan Non Formal; (2) Seksi Kurikulum dan Sistem Pengkajian Pendidikan Informal dan Non Formal; (3) Seksi Sarana dan Prasarana Pendidikan Informal dan Non Formal. Sedangkan Bidang Peningkatan Mutu Pendidik dan Tenaga Kependidikan terdiri dari (1) Seksi Pembina Tenaga Pendidik dan Tenaga Kependidikan Dasar; (2) Seksi Pembinaan Profesi Pendidik dan Tenaga Kependidikan Menengah dan Fungsional; (3) Seksi Peningkatan Mutu Profesi Pendidik dan Tenaga Kependidikan Dikdasmen. Adapun jumlah staf/pegawai yang menjadi bawahan masing-masing kepala seksi tersebut secara keseluruhan adalah 129 pegawai.

Hasil pengamatan sementara peneliti menunjukkan bahwa terdapat ketidakpuasan pegawai atas kepemimpinan kepala seksi yang menjadi atasan mereka. Hal ini dapat dilihat banyaknya pegawai yang kurang memberikan upaya untuk melaksanakan pekerjaannya dengan seringnya pegawai datang terlambat dan seringnya pegawai cepat pulang sebelum waktunya, serta banyaknya pegawai yang hanya dudukduduk santai pada waktu jam kerja. Faktor-faktor yang diduga menjadi penyebab adanya ketidakpuasan pegawai terhadap kepemimpinan atasannya adalah harapan pegawai yang rendah, dimana pegawai hanya memberikan upaya yang sedikit dalam pekerjaannya karena adanya perilaku pemimpin yang kurang memberikan penghargaan atas upaya bawahannya. Faktor-faktor lain yang diduga menjadi penyebab rendahnya harapan bawahan dan kepuasan atas kepemimpinan adalah perilaku pemimpin yang kurang memberikan motivasi kepada bawahannya untuk berupaya maksimal dan memberikan penghargaan yang diharapkan oleh bawahannya, serta adanya faktor karakteristik tugas yang diduga juga mempengaruhi rendahnya harapan bawahan dan kepuasan atas kepemimpinan. Untuk keperluan penelitian disertasi ini, peneliti menggunakan model teori yang disusun oleh Gary Yukl. Menurut Gary Yukl, variabel kepuasan bawahan atas kepemimpinan dipengaruhi oleh variabel perilaku pemimpin, karakteristik tugas, karakteristik lingkungan, karakteristik bawahan serta harapan dan valensi bawahan atas kepemimpinan. Dari model tersebut, dijelaskan hubungan sebab akibat dalam Teori Jalur-Sasaran dari kepemimpinan. Dari beberapa variabel yang terdapat pada model tersebut peneliti hanya memilih tiga variabel yang mempengaruhi kepuasan bawahan atas kepemimpinan yaitu perilaku pemimpin, karakteristik tugas dan harapan bawahan.

Perilaku Pemimpin. Robbins (2006: 432) mendefinisikan perilaku pemimpin sebagai kemampuan untuk mempengaruhi kelompok menuju pencapaian sasaran. Menurut Daft (2006:8), perilaku pemimpin merupakan penggunaan pengaruh untuk memberikan motivasi kepada karyawan untuk mencapai tujuan organisasi. Perilaku pemimpin menurut McShane dan Von Glinow (2008: 402)," about influencing, motivating, and enabling others to contribute toward the effectiveness and success of the organization of which they are member". Salah satu teori yang menghubungkan perilaku pemimpin dan persepsi situasi bawahan dan cukup berpengaruh dalam kehidupan organisasi ialah Path-Goal Theory. Model kepemimpinan path-goal theory mengadaptasi kepemimpinan situasional. Model ini didasarkan pada motivasi bawahan atas pengharapannya atau tujuannya mendapatkan imbalan. Peranan pemimpin adalah menjelaskan kepada bawahannya cara mencapai tujuan. Organisasi efektif tergantung pada kemampuan pemimpin memuaskan kebutuhan bawahannya dan kemampuan pemimpin memberi petunjuk kepada bawahannya.

Perilaku pemimpin menurut McShane dan Von Glinow (2008:409) ada empat yaitu perilaku pemimpin mengarahkan (directive), suportif (supportive), partisipatif 
(participative) dan perilaku pemimpin berorientasi keberhasilan (achievement-oriented). Selanjutnya Luthans (2008: 421) menjelaskan keempat perilaku tersebut sebagai berikut: (1) Directive leadership. Associates know exactly what is expected of them, and the leader gives specific directions. There is no participation by subordinates; (2) Supportive leadership. The leader is friendly and approachable and shows a genuine concern for associates; (3) Participative leadership. the leader asks for and uses suggestion from associates but still makes the decisions; (4) Achievement-oriented leadership. The leader sets challenging goals for associates and shows confidence that they will attain these goals and perform well. Berdasarkan uraian diatas dapat disimpulkan bahwa perilaku pemimpin adalah tingkah laku seseorang/atasan dalam mempengaruhi orang lain/bawahan untuk pencapaian tujuan dengan memberikan pengarahan, bimbingan, dukungan, dan penghargaan.

Karakteristik Tugas. Teori karakteristik tugas (task characteristic theory) menurut Robbins (2006: 637) adalah upaya mengidentifikasi karakteristik tugas pekerjaan, bagaimana gabungan karakteristik itu membentuk pekerjaan-pekerjaan yang berbeda, dan hubungan karakteristik itu dengan motivasi, kepuasan, dan kinerja karyawan. Teori motivasi-higiene Herzberg mengenai kebutuhan (motif) berprestasi pada hakikatnya merupakan teori karakteristik tugas. Herzberg mengemukakan bahwa pekerjaanpekerjaan yang memberikan kesempatan untuk berprestasi, mendapat pengakuan, tanggung jawab, dan sejenisnya, akan meningkatkan kepuasan karyawan. Selanjutnya Herzberg meyakini bahwa hubungan individu dengan pekerjaannya itu merupakan hubungan yang mendasar dan bahwa sikap individu tersebut terhadap pekerjaannya menentukan kesuksesan atau kegagalan. Sama halnya, Mc Clelland yang telah mengemukakan teori tiga kebutuhan yang menyatakan kebutuhan akan pencapaian prestasi, kekuasaan, dan afiliasi merupakan motif utama dalam pekerjaan. Teori Mc Clelland ini, memperlihatkan bahwa mereka yang berprestasi tinggi paling baik menjalankan pekerjaan yang menawarkan tanggung jawab pribadi, umpan balik, dan risiko yang sedang.

Model karakteristik pekerjaan menurut George dan Jones (2005: 208)," Job characteristics model as an approach to job design that aims to identify characteristics that make job instrinsically motivating and the consequences of those characteristics". Menurut Griffin (2002: 326), pendekatan karakteristik pekerjaan adalah suatu alternatif spesialisasi pekerjaan yang menyarankan agar pekerjaan seharusnya didiagnosis dan ditingkatkan sejalan dengan lima dimensi, dengan memperhitungkan sistem kerja dan preferensi karyawan. Menurut Robbins dan Coulter (2007:143), model karakteristik pekerjaan adalah kerangka kerja yang menganalisis dan merancang pekerjaan yang mengenali lima ciri utama pekerjaan, hubungan antar pribadi, dan dampaknya pada hasil.

Pendekatan karakteristik pekerjaan terhadap perancangan pekerjaan memberikan suatu alternatif lain yang dapat dipraktikkan untuk menggantikan spesialisasi pekerjaan. Lima dimensi pekerjaan inti dapat menyebabkan kondisi psikologis kritis yang, pada akhirnya, akan meningkatkan motivasi, kinerja dan kepuasan, di lain pihak juga mengurangi ketidakhadiran dan perputaran. Pendekatan karakteristik pekerjaan menyebutkan bahwa pekerjaan seharusnya didiagnosis dan ditingkatkan sejalan dengan lima dimensi inti, yaitu ragam keahlian, identitas tugas,

signifikansi tugas, otonomi, dan umpan balik. Model karakteristik pekerjaan tersebut berusaha untuk memperhitungkan hubungan saling ketergantungan antara (1) beberapa karakteristik pekerjaan, (2) keadaan psikologis yang dihubungkan dengan motivasi, kepuasan, dan kinerja, (3) hasil pekerjaan, dan (4) kekuatan kebutuhan akan 
pertumbuhan. Model ini mendeskripsikan hubungan antara variabel-variabel tersebut. Walaupun keragaman, identitas, signifikansi, otonomi, dan umpan balik tidak sepenuhnya mendeskripsikan konten pekerjaan yang dipersepsikan, cukup menggambarkan berdasarkan model ini, aspek-aspek yang dapat dimanipulasi oleh manajemen untuk menghasilkan keuntungan dalam produktivitas.

Dalam istilah umum, menurut Kreiner dan Kinicki (2007: 256) dimensi inti dari pekerjaan adalah karakteristik umum yang ditemukan pada berbagai tingkatan pekerjaan. Kombinasi dari tiga di antara karakteristik itu menentukan begitu berartinya pekerjaan. Karakteristik itu adalah: skill variety, task identity dan task significance. Menurut McShane dan Von Glinow (2008:179)," skill variety refers to the use of different skills and talents to complete a variety of work activities". Keragaman keterampilan. Lingkup di mana pekerjaan memerlukan seorang individu yang mampu melakukan berbagai tugas yang mengharuskannya menggunakan keterampilan dan kemampuan yang berbeda. Kemudian McShane dan Von Glinow (2008: 179) menjelaskan, "task identity is the degree to which a job requires completion of a whole or an identifiable piece of work". Identitas tugas. Lingkup di mana pekerjaan mengharuskan seorang individu untuk melaksanakan seluruh pekerjaan secara lengkap yang dapat diidentifikasi. Dengan kata lain, tingginya identitas tugas tampak pada saat seseorang mengerjakan suatu produk atau suatu proyek sejak awal hingga akhir dan membuat hasil yang nyata. Selanjutnya McShane dan Von Glinow menjelaskan," task significance is the degree to which the job affects the organization an or society. Signifikansi tugas. Lingkup di mana pekerjaan mempengaruhi kehidupan orang lain di dalam ataupun di luar organisasi. Berdasarkan uraian diatas dapat disimpulkan bahwa karakteristik tugas adalah kompleksitas pekerjaan dan hubungannya dengan keberhasilan kerja individu/bawahan dengan indikator mengenali bidang pekerjaan, memahami pencapaian tujuan pekerjaan, keyakinan akan keberhasilan kerja, kebebasan kerja, dan penilaian hasil kerja.

Harapan Bawahan. Menurut Jones dan George (2008: 523), "Expectancy is a person's perception about the extent to which effort (an input) results in a certain level of performance". Jadi teori harapan mengatakan bahwa karyawan dimotivasi untuk melakukan upaya lebih keras bila ia meyakini upaya itu akan menghasilkan penilaian kinerja yang baik. Pemimpin meningkatkan motivasi karyawan dengan cara mengklarifikasikan jalan menuju reward yang tersedia, atau meningkatkan reward yang diinginkan dan diharapkan oleh karyawan. Teori harapan menurut Robbins (2006: 238), berargumen bahwa kekuatan dari kecenderungan untuk bertindak dengan cara tertentu bergantung pada kekuatan pengharapan bahwa tindakan itu akan diikuti oleh output tertentu dan tergantung pada daya tarik output itu bagi individu tersebut.

Menurut Robbins dan Judge (2008: 254), teori harapan berfokus pada tiga hubungan (1) Hubungan usaha-kinerja. Kemungkinan yang dirasakan oleh individu yang mengeluarkan sejumlah usaha akan menghasilkan kinerja; (2) Hubungan kinerjapenghargaan. Tingkat sampai mana individu yakin bahwa bekerja pada tingkat tertentu akan menghasilkan pencapaian yang diinginkan; dan (3) Hubungan penghargaantujuan-tujuan pribadi. Tingkat sampai mana penghargaan-penghargaan organisasional memuaskan tujuan-tujuan pribadi atau kebutuhan-kebutuhan individu dan daya tarik dari penghargaan-penghargaan potensial bagi individu tersebut. Menurut Kreiner dan Kinicki (2007: 246), Victor Vroom merumuskan teori harapan pada tahun 1964. teori Vroom telah dirangkum sebagai berikut, "The strength of a tendency to act in a certain way depends on the strength of an expectancy that the act will be followed by a given consequence (or outcome) and on the value or attractiveness of that concequence (or outcome) to the actor". Jadi menurut Vroom, teori harapan adalah kecenderungan yang kuat untuk bertindak 
dengan suatu cara tertentu tergantung pada kekuatan harapan bahwa tindakan akan diikuti dengan suatu konsekuensi tertentu (atau akibat tertentu) dan pada tertarik pada konsekuensi (atau akibat) bagi pelakunya. Tiga konsep kunci didalam model Vroom, yaitu harapan (expectancy), alat (instrumentaly), dan penilaian (valensi).

Teori harapan menurut McShane dan Von Glinow (2008:143), "Expectancy theory is based on the idea that work effort is directed toward behaviors that people believe will lead to desired outcomes". Teori harapan menurut Ivancevich dan Matteson adalah suatu teori motivasi yang menyatakan bahwa karyawan lebih mungkin termotivasi ketika mereka mempersepsikan usaha mereka akan menghasilkan kinerja yang berhasil dan pada akhirnya menghasilkan penghargaan dan hasil yang diinginkan. Selanjutnya menurut Ivancevich dan Matteson (2002:160), " expectancy refers to individual's belief regarding the likelihood or subjective probability that a particular behavior will be followed by a particular outcome, and it is most easily thought of as a single-probability statement". Harapan merujuk pada keyakinan individu berkenaan dengan kemungkinan, atau probabilitas subyektif, bahwa suatu perilaku tertentu akan diikuti dengan hasil tertentu, dan paling mudah dipahami sebagai pernyataan probabilitas tunggal. Ini berarti hal tersebut merujuk pada suatu kesempatan yang dipersepsikan dari sesuatu akan muncul karena perilaku.

Menurut Weihrich dan Koontz (2005:375), "expectancy is the probability that a particular action will lead to a desired outcome". Harapan adalah besarnya kemungkinan bahwa upaya yang dilakukan akan berhasil. Harapan dinyatakan sebagai kemungkinan prestasi seseorang terhadap usaha yang dilakukannya. Selanjutnya, ada dua kondisi yang harus dipenuhi harapan yaitu (1) kemampuan yang memadai untuk melaksanakan tugas, dan (2) persepsi yang akurat tentang peranan seseorang dalam organisasi. Wexley dan Yukl (2005:218) menjelaskan bahwa menurut teori harapan, motivasi pekerja sangat ditentukan oleh harapannya bahwa suatu usaha yang mencapai tingkat pelaksanaan kerja terbaik akan menjadi alat untuk mendapatkan hasil-hasil yang positif dan menghindarkan hasil-hasil yang negatif. Selanjutnya menurut Wexley dan Yukl, teori path-goal menjelaskan bagaimana perilaku pemimpin mempengaruhi harapan-harapan ini, pada gilirannya mempengaruhi pelaksanaan kerja bawahan. Proposisi utama dari teori ini menurut Wexley dan Yukl adalah bahwa perilaku pemimpin akan meningkatkan harapan bawahan sejauh: (1) pemimpin memuaskan kebutuhan-kebutuhan para bawahan yang dikaitkan dengan pelaksanaan kerja yang efektif, dan (2) pemimpin memberikan latihan, bimbingan dan dukungan yang diperlukan. Dari uraian diatas dapat disimpulkan bahwa harapan bawahan adalah upaya bawahan untuk menyelesaikan pekerjaan yang ditugaskan dan mendapatkan imbalan yang sesuai dari atasan dengan indikator adanya keinginan untuk berprestasi, dorongan bekerja dengan baik, berusaha mencapai tujuan dan adanya keinginan mendapatkan imbalan

Kepuasan Atas Kepemimpinan. Dalam penelitian ini kita melihat kepuasan sebagai sikap (attitude). Menurut Robbins dan Judge (2008:92), sikap (attitude) adalah pernyataan evaluatif-baik yang menyenangkan maupun tidak menyenangkan terhadap objek, individu, atau peristiwa. Hal ini mencerminkan bagaimana perasaan seseorang tentang sesuatu. Sikap didefinisikan oleh Robert Kreitner dan Angelo Kinicki (2007: 182), sebagai kecenderungan merespons sesuatu secara konsisten untuk mendukung atau tidak mendukung dengan memperhatikan suatu objek tertentu. (An attitude is defined as "a learned predisposition to respond in a consistently favorable or unfavorable manner with 
respect to a given object"). Sehingga kepuasan adalah suatu efektivitas atau respons emosional terhadap berbagai aspek kepemimpinan.

Ada lima model penyebab kepuasan menurut Kreitner dan Kinicki (2007: 271), adalah pemenuhan kebutuhan, ketidakcocokan, pencapaian nilai, keadilan, dan komponen watak / genetik. Model pemenuhan kebutuhan menjelaskan bahwa kepuasan ditentukan oleh karakteristik dari sebuah pekerjaan memungkinkan seorang individu untuk memenuhi kebutuhannya. Model ketidakcocokan menjelaskan bahwa kepuasan adalah hasil dari harapan yang terpenuhi. Harapan yang terpenuhi mewakili perbedaan antara apa yang diharapkan oleh seorang individu dari sebuah pekerjaan, seperti upah dan kesempatan promosi yang baik, dan apa yang pada kenyataannya diterimanya. Pada saat harapan lebih besar daripada yang diterima, seseorang akan tidak puas. Sebaliknya, model ini memprediksikan bahwa individu akan puas pada saat ia mempertahankan output yang diterimanya dan melampaui harapan pribadinya. Model pencapaian nilai menjelaskan bahwa kepuasan berasal dari persepsi bahwa suatu pekerjaan memungkinkan untuk pemenuhan nilai-nilai kerja yang penting dari seorang individu. Model keadilan menjelaskan bahwa kepuasan adalah suatu fungsi dari bagaimana seorang individu diperlakukan "secara adil" di tempat kerja. Kepuasan berasal dari persepsi seseorang bahwa output pekerjaan, relatif sama dengan inputnya, perbandingan yang mendukung output/input lain yang signifikan. Serta model komponen watak/genetik menjelaskan bahwa model ini didasarkan pada keyakinan bahwa kepuasan merupakan sebagian fungsi dari sifat pribadi maupun faktor genetik.

Fred Luthans (2006:-243) menjelaskan bahwa ada tiga dimensi kepuasan karyawan. Pertama, kepuasan merupakan respons emosional terhadap situasi kerja. Kedua, kepuasan sering ditentukan menurut seberapa baik hasil yang dicapai memenuhi atau melampaui harapan. Ketiga, kepuasan mewakili beberapa sikap yang berhubungan. Teori path-goal menekankan tanggung jawab pemimpin untuk meningkatkan motivasi karyawan agar tujuan personal dan organisasional tercapai. Pemimpin meningkatkan motivasi bawahan dengan cara mengklarifikasikan jalan (path) menuju reward yang tersedia, atau meningkatkan reward yang diinginkan dan diharapkan oleh bawahan. klarifikasi jalan artinya pemimpin bekerja dengan bawahan untuk menolong mereka mengidentifikasikan dan belajar tentang perilaku apa saja, yang akan membawa penyelesaian tugas yang efektif serta mencapai reward organisasi. Tugas pemimpin menurut teori ini adalah bagaimana seorang pemimpin menjelaskan dan mempermudah jalan menuju reward tersebut. Pemimpin berusaha memperjelas jalur menuju tujuan yang diinginkan oleh organisasi sehingga bawahan tahu kemana harus mengerahkan tenaganya untuk mencapai tujuan organisasi. Berdasarkan uraian diatas dapat disimpulkan bahwa kepuasan atas kepemimpinan adalah suatu perasaan positif seseorang/bawahan atas kepemimpinan atasannya dengan indikator perasaan atas

kepemimpinan suportif, kepemimpinan mengarahkan, kepemimpinan partisipatif, dan kepemimpinan berorientasi keberhasilan.

\section{METODE}

Metode yang digunakan dalam penelitian ini adalah metode survei dengan pendekatan kausal. Populasi penelitian ini adalah semua pegawai yang menjadi bawahan kepala seksi di Lingkungan Dinas Pendidikan Kabupaten Donggala Propinsi Sulawesi Tengah yang berjumlah 129 pegawai. Sampel penelitian diambil secara acak dan berjumlah 97 sampel. 


\section{HASIL DAN PEMBAHASAN}

\section{Pengaruh langsung Perilaku Pemimpin $\left(X_{1}\right)$ terhadap Harapan Bawahan $\left(X_{3}\right)$}

Uji hipotesis dapat dilakukan dengan bantuan program SPSS 16 pada taraf $a=0,05$. Berdasarkan hasil perhitungan diperoleh nilai signifikansi lebih kecil daripada nilai $\alpha=$ 0,05. Maka Ho ditolak dan menerima $\mathrm{H}_{1}$. Dengan demikian dapat dikatakan bahwa: hipotesis yang diajukan dengan pernyataan terdapat pengaruh langsung perilaku pemimpin terhadap harapan bawahan dapat diterima. Dengan ditolaknya hipotesis Ho maka diyakini bahwa perilaku pemimpin mempunyai pengaruh positif dan signifikan terhadap harapan bawahan.

\section{Pengaruh langsung Karakteristik Tugas $\left(X_{2}\right)$ terhadap Harapan Bawahan $\left(X_{3}\right)$}

Uji hipotesis dapat dilakukan dengan bantuan program SPSS 16 pada taraf $a=0,05$. Berdasarkan hasil perhitungan diperoleh nilai signifikansi lebih kecil daripada nilai $\alpha=$ 0,05. Maka Ho ditolak dan menerima $\mathrm{H}_{1}$. Dengan demikian dapat dikatakan bahwa: hipotesis yang diajukan dengan pernyataan terdapat pengaruh langsung karakteristik tugas terhadap harapan bawahan dapat diterima. Dengan ditolaknya hipotesis Ho maka diyakini bahwa karakteristik tugas mempunyai pengaruh positif dan signifikan terhadap harapan bawahan.

Pengaruh langsung Harapan Bawahan $\left(X_{3}\right)$ terhadap Kepuasan Atas kepemimpinan $\left(X_{4}\right)$

Uji hipotesis dapat dilakukan dengan bantuan program SPSS 16 pada taraf $a=0,05$. Berdasarkan hasil perhitungan diperoleh nilai signifikansi lebih kecil daripada nilai $\alpha=$ 0,05. Maka Ho ditolak dan menerima $\mathrm{H}_{1}$. Dengan demikian dapat dikatakan bahwa: hipotesis yang diajukan dengan pernyataan terdapat pengaruh langsung harapan bawahan terhadap kepuasan atas kepemimpinan dapat diterima. Dengan ditolaknya hipotesis Ho maka diyakini bahwa harapan bawahan mempunyai pengaruh positif dan signifikan terhadap kepuasan atas kepemimpinan.

\section{Pengaruh tidak langsung Perilaku Pemimpin $\left(X_{1}\right)$ terhadap Kepuasan Atas} kepemimpinan $\left(X_{4}\right)$ melalui Harapan Bawahan $\left(X_{3}\right)$

Uji hipotesis dapat dilakukan dengan bantuan program SPSS 16 pada taraf $a=0,05$. Berdasarkan hasil perhitungan diperoleh nilai signifikansi 0,00 lebih kecil daripada nilai $\mathrm{a}=0,05$. Maka Ho ditolak dan menerima $\mathrm{H}_{1}$. Dengan demikian dapat dikatakan bahwa: hipotesis yang diajukan dengan pernyataan terdapat pengaruh tidak

langsung perilaku pemimpin terhadap kepuasan atas kepemimpinan melalui harapan bawahan dapat diterima. Dengan ditolaknya hipotesis Ho maka diyakini bahwa perilaku pemimpin melalui harapan bawahan mempunyai pengaruh tidak langsung yang positif dan signifikan terhadap kepuasan atas kepemimpinan.

\section{Pengaruh tidak langsung Karakteristik Tugas $\left(X_{2}\right)$ terhadap Kepuasan Atas} kepemimpinan $\left(\mathrm{X}_{4}\right)$ melalui Harapan Bawahan $\left(\mathrm{X}_{3}\right)$

Uji hipotesis dapat dilakukan dengan bantuan program SPSS 16 pada taraf $a=0,05$. Berdasarkan hasil perhitungan diperoleh nilai signifikansi 0,01 lebih kecil daripada nilai $a=0,05$. Maka Ho ditolak dan menerima $\mathrm{H}_{1}$. Dengan demikian dapat dikatakan bahwa: hipotesis yang diajukan dengan pernyataan terdapat pengaruh tidak langsung karakteristik tugas terhadap kepuasan atas kepemimpinan melalui harapan bawahan 
dapat diterima. Dengan ditolaknya hipotesis Ho maka diyakini bahwa karakteristik tugas melalui harapan bawahan mempunyai pengaruh tidak langsung yang positif dan signifikan terhadap kepuasan atas kepemimpinan.

\section{Perhitungan Pengaruh Langsung, Tidak Langsung, dan Pengaruh Total Antarvariabel}

\section{Pengaruh Langsung}

Hasil Perhitungan pengaruh langsung menggunakan program SPSS 16 adalah: pengaruh variabel perilaku pemimpin terhadap harapan adalah $\mathbf{0 , 7 2 8 ;}$ pengaruh variabel karakteristik tugas terhadap harapan bawahan adalah 0,807; pengaruh variabel harapan bawahan terhadap kepuasan atas kepemimpinan adalah 0,739.

\section{Pengaruh Tidak Langsung}

Hasil perhitungan pengaruh tidak langsung menggunakan SPSS 16 adalah: pengaruh variabel perilaku pemimpin terhadap kepuasan atas kepemimpinan melalui harapan bawahan adalah 538; pengaruh variabel karakteristik tugas terhadap kepuasan atas kepemimpinan melalui harapan bawahan adalah 0,596

\section{Pengaruh Total}

Hasil perhitungan pengaruh total adalah pengaruh variabel perilaku pemimpin terhadap kepuasan atas kepemimpinan melalui harapan bawahan adalah 0,467; pengaruh variabel karakteristik tugas terhadap kepuasan atas kepemimpinan melalui harapan bawahan adalah 0,546; pengaruh variabel harapan bawahan terhadap kepuasan atas kepemimpinan adalah 0,739

\section{PENUTUP}

Kesimpulan. Berdasarkan hasil analisis data, maka dapat disampaikan kesimpulan penelitian sebagai berikut: (1)Perilaku pemimpin berpengaruh langsung terhadap harapan bawahan; (2) Karakteristik tugas berpengaruh langsung terhadap harapan bawahan; (3) Harapan bawahan berpengaruh langsung terhadap kepuasan atas kepemimpinan; (4) Perilaku pemimpin berpengaruh tidak langsung terhadap kepuasan atas kepemimpinan melalui harapan bawahan; (5) Karakteristik tugas berpengaruh tidak langsung terhadap kepuasan atas kepemimpinan melalui harapan bawahan.

Saran. (1) Seorang pemimpin dalam hal ini seorang atasan hendaknya dapat mengarahkan bawahannya dengan jelas ketujuan bersama, memberikan penghargaan kepada bawahannya yang berprestasi secara adil, memberikan kesempatan kepada bawahan untuk mendiskusikan masalah pekerjaannya, membimbing dan mendorong semangat bawahan untuk bekerja lebih giat, sehingga harapan bawahan dapat terwujud yang dapat meningkatkan kepuasan atas kepemimpinan atasannya; (2) Seorang pegawai dalam hal ini seorang bawahan hendaknya dapat mengenali bidang pekerjaannya, memahami pencapaian tujuan pekerjaan, mempunyai keyakinan akan keberhasilan kerja, mempunyai kebebasan kerja, dan mendapatkan penilaian hasil kerja, sehingga harapan bawahan dapat terwujud yang dapat meningkatkan kepuasan atas kepemimpinan atasannya; (3) Seorang pegawai hendaknya memberikan upaya untuk berprestasi, bekerja dengan baik, berusaha mencapai tujuan dan mendapatkan imbalan berupa promosi, pujian, dan pengakuan dari atasannya atas kemampuan kerja yang dimilikinya, dengan terwujudnya harapan bawahan ini dapat meningkatkan kepuasan 
atas kepemimpinan; (4) Para pegawai di Lingkungan Dinas Pendidikan baik yang menjadi seorang atasan maupun seorang bawahan harus lebih memperhatikan masalah kepuasan atas kepemimpinan dalam rangka memperbaiki faktor-faktor penyebabnya. Perhatian khususnya diarahkan pada perilaku pemimpin atau seorang atasan, karakteristik tugas seorang bawahan dan harapan bawahan atau pegawai; (5) Para peneliti di bidang pendidikan perlu melakukan kajian lebih lanjut mengenai variabelvariabel lain yang secara langsung berpengaruh terhadap kepuasan atas kepemimpinan. Hal ini perlu dilaksanakan mengingat bahwa pengaruh langsung harapan bawahan terhadap kepuasan atas kepemimpinan hanya berkisar 55\%. Dengan demikian masih ada sekitar $45 \%$ variabel lain yang berpengaruh langsung terhadap kepuasan atas kepemimpinan. 


\section{DAFTAR RUJUKAN}

Daft, Richard L, Management, Manajemen. Alih Bahasa Edward Tanujaya dan Shirly Tiolina. . Jakarta: Penerbit Salemba Empat, 2006.

George, Jennifer M dan Gareth R. Jones, Understanding and Managing Organizational Behavior. New Jersey: Pearson Prentice hall, 2005.

Griffin, Ricky W, Manajemen. Alih Bahasa Gina Gania. Jakarta: Penerbit Erlangga, 2002.

Ivancevich, John M dan Michael T. Matteson, Organizational Behavior and Management. New York: McGraw-Hill, Inc., 2002.

Kreiner, Robert dan Angelo Kinicki, Organizational Behavior. New York: McGraw-Hill, Inc., 2007

Luthans, Fred, Organizational Behavior, Perilaku Organisasi. Alih Bahasa Vivin, dan lainlain. Yogyakarta: Penerbit Andi, 2006.

Organizational Behavior. New York: McGraw-Hill, Inc., 2008.

McShane dan Von Glinow, Organizational Behavior. New York: McGraw-Hill, Inc., 2008.

Robbins, Stephen P dan Mary Coulter, Management; Manajemen. Alih Bahasa Harry Slamet dan Ernawati Lestari. Jakarta: Penerbit PT. Indeks, 2007.

Robbins, Stephen P dan Timothy A. Judge, Organizational Behavior; Perilaku Organisasi. Alih Bahasa Diana Angelica. Jakarta: Penerbit Salemba Empat,2008

Robbins, Stephen P, Organizational Behavior , Perilaku Organisasi. Alih Bahasa Benyamin Molan. . Jakarta: Penerbit PT. Indeks, 2006

Weihrich, Heinz dan Harold Koontz, Management. New York: McGraw-Hill, Inc., 2008.

Wexley, Kenneth.N dan Gary Yukl, Perilaku Organisasi dan Psikologi Personalia. Jakarta: PT Rineka Cipta, 2005. 